\title{
Politik Hukum Kewenangan Pemerintah Daerah Dalam Pengaturan Hak Kekayaan Intelektual
}

\author{
Darwance $^{1 *}$, Yokotani $^{1}$, Wenni Anggita ${ }^{2}$ \\ ${ }^{1}$ Jurusan Hukum, Fakultas Hukum, Universitas Bangka Belitung, 33172, Bangka-Indonesia \\ ${ }^{2}$ Jurusan Akuntansi, Fakultas Ekonomi, Universitas Bangka Belitung, 33172, Bangka-Indonesia
}

\begin{tabular}{l}
\hline Info Artikel \\
\hline Dikirim: Nov 03, 2020 \\
Diterima: Jan 28, 2021 \\
Dipublikasi: Jan 31, 2021 \\
\hline Kata Kunci: \\
Hak Kekayaan Intelektual; \\
Peraturan; \\
Politik Hukum; \\
\hline
\end{tabular}

Koresponden:

Darwance

Jurusan Hukum

Universitas Bangka Belitung

\section{Email:}

darwance@yahoo.co.id

\section{Sitasi Cantuman:}

Darwance, Yokotani \& Anggita, W. (2021). Politik Hukum Kewenangan Pemerintah Daerah Dalam Pengaturan Hak Kekayaan Intelektual. Journal of Political Issues. 2(2); 124134. https://doi.org/10.33019/jpi.v $2 \mathrm{i} 2.40$

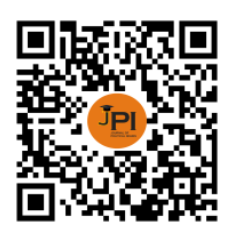

DOI:

https://doi.org/10.33019/jpi.v $2 \mathrm{i} 2.40$

Lisensi:

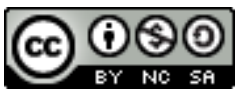

Attribution-NonCommercialShareAlike 4.0 International (CC- BY-NC-SA 4.0)

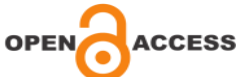

\begin{abstract}
ABSTRAK
Abstract The objects of protection for intellectual property rights are vary greatly. Along with the development of science and technology, the objects of protection for intellectual property rifghts are developing from time to time. The objects are not only in one place. In Indonesia, the protected potential objects spread in various region. In some IPR branches, one of the reasons in because the communal ownership or the discover is no longer known, the IPR perspective cannot be protected, for example traditional knowledge or medicines. Some ofe the case include piracy of biodiversity from knowledge of traditional Indonesian medicines, namely the patenting of the brotowali plant by Japanes company. On the other hand, the statutory regulations on IPRs have minimal direct authority to local governments regarding IPR protection. Therefore, this normative research with laws and regulations approach exemines legal politics of local government authority in laws and regulations in the field of intellectual property rights. The result is from all of laws and regulations in the field of IPR, explicitly the authority of local government is only regulated in Law Number 20 Year 2016 Concerning on Mark and Geographical Indications. The rest is general in nature, for example the use of the term "state" in the Copyrights Law as the holder of traditional cultural expressions and copyright of works whose creatoris unknown. In fact, in the context of a rule of law, government authority derives from the prevailing laws and regulations, in line with the legality principle which is the basis in every state and government administration.
\end{abstract}

Abstrak Seiring dengan perkembangan ilmu pengetahan dan teknologi, objek perlindungan hak kekayaan intelektual pun semakin berkembang dari waktu ke waktu. Objek-objek yang dimaksud tidak hanya ada di satu tempat saja, tetapi menyebar di berbagai daerah. Pada beberapa cabang HKI, salah satunya karena kepemilikan komunal atau penemunya tidak lagi diketahui, tidak dapat diberikan perlindungan perspektif HKI, misalnya pengetahuan atau obat-obatan tradisional. Beberapa kasus di antaranya adalah pembajakan keanekaragaman hayati dari pengetahun obat-obatan tradisional Indonesia, yakni dipatenkannya tanaman brotowali oleh perusahaan Jepang. Di sisi lain, peraturan perundang-undangan bidang HKI minim memberikan kewenangan secara langsung kepada pemerintah daerah berkaitan dengan perlindungan HKI. Oleh sebab itu, penelitian yang bersifat normatif dengan pendektan peraturan perundang-undangan ini mengkaji politik hukum tentang kewenangan pemerintah daerah dalam peraturan perundangundangan di bidang hak kekayaan intelektual. Hasilnya, dari seluruh peraturan perundangundangan bidan HKI, kewenangan pemerintah daerah secara eksplisit hanya diatur dalam Undang-Undang Merek dan Indikasi Geografis. Selebihnya penyebutannya bersifat umum, misalnya penggunaan istilah "negara" dalam Undang-Undang Hak Cipta sebagai pemegang ekspresi budaya tradisional dan hak cipta atas ciptaan yang penciptanya tidak diketahui. Padahal, dalam konteks negara hukum, wewenang pemerintahan berasal dari peraturan perundang-undangan yang berlaku, sejalan dengan asas legalitas yang merupakan dasar dalam setiap penyelenggaraa kenegaraan dan pemerintahan.

\footnotetext{
Tentang:

Darwance, menyelesaikan studi (S2) di Fakultas Hukum Universitas Gadjah Mada Yogyakarta pada tahun 2014. Saat ini penulis adalah dosen tetap di Fakultas Hukum Universitas Bangka Belitung.

Yokotani, menyelesaikan studi (S2) di Sekolah Tinggi Ilmu Hukum (STIH) Pertiba pada tahun 2011. Saat ini penulis adalah dosen tetap di Fakultas Hukum Universitas Bangka Belitung.

Wenni Anggita, menyelesaikan studi (S2) Jurusan Akuntansi di Fakultas Ekonomika dan Bisnis Universitas Diponegoro Semarang pada tahun 2014. Saat ini penulis adalah dosen tetap di Jurusan Akuntansi Fakultas Ekonomi Universitas Bangka Belitung.
} 


\section{PENDAHULUAN}

Pada dasarnya, manusia dilahirkan dalam kondisi memiliki kemampuan yang berbeda-beda. Dapat pula dikatakan bahwa antara manusia yang satu dengan manusia yang lain, sekalipun umpamanya memiliki potensi yang sama dalam konteks kreativitas, akan tetapi memiliki tingkat keahlian yang berbeda sehingga luaran yang dihasilkan menjadi berbeda pula. Contoh sederhana, tidak semua orang pandai menciptakan lagu. Sekalipun beberapa orang yang memiliki kemampuan yang sama, yakni sama-sama bisa menciptakan lagu, tingkat kepiawaian mereka dalam menciptakan lagu menempati level yang berbeda. Salah seorang di antara mereka bukan hanya bisa menciptakan lagu, tapi lagu-lagu yang ia ciptakan selalu enak dan nyaman di telinga. Sementara salah seorang lagi, bisa menciptakan lagu tapi lagu ciptaanya dianggap biasa-biasa saja.

Dengan beberapa dasar pemikiran, salah satunya bahwa setiap orang memiliki kemampuan yang berbeda dalam mengelola intelektualitasnya, maka lahirlah kemudian konsep perlindungan terhadapnya yang dikenal dengan Hak Kekayaan Intelektual (HKI). HKI salah satunya dimaknai sebagai istilah hukum umum untuk paten, hak cipta, dan merek dagang, yang memberikan hukum hak untuk melindungi ide, ekspresi ide, dan penemu atau pencipta gagasan semacam itu (Rout, 2018). Pada perkembangannya kemudian, cakupan atau objek perlindungan HKI terus berkembang yang semula hanya hak cipta, paten, dan merek, bertambah di antaranya adalah rahasia dagang, desain industri, desain tata letak sirkuit terpadu, perlindungan varietas tanaman, dan indikasi geografis.

Dari aspek historis, secara global dikatakan bahwa HKI bermula dari sejumlah invensi yang berhasil diwujudkan oleh beberapa penemu di Eropa (Saidin, 2019). HKI pada praktiknya memang lebih dahulu berkembang di negara maju. Sedangkan di negara-negara berkembang, termasuk Indonesia, HKI baru menjadi perhatian beberapa dekade terakhir, terutama setelah negara berkembang meratifikasi pembentukan World Trade Organiation (WTO) yang salah satu konsekuensinya adalah harus menyesuaikan pengaturan tentang HKI di negara masing-masing sesuai dengan kehendak WTO. Di Indonesia, sekalipun aturan tentang HKI sudah ada sejak sebelum kemerdekaan, tetapi perhatian terhadap HKI baru betul-betul diseriusi sejak awal tahun 1980-an, ditandai dengan beberapa produk hukum yang mengatur tentang cabang dari HKI, seperti hak cipta, paten, merek, dan lain sebagainya.

Penerapan HKI di Indonesia praktiknya berhadapan dengan sejumlah hal yang dapat pula dikatakan sebagai kendala dalam ranah implementasi. Hal ini diakibatkan oleh konsep HKI yang didominasi oleh hak-hak yang bersifat individualistik (hak kepemilikan indivdu), sementara karakter masyarakat Indonesia adalah komunalistik yang lebih mengutamakan kepentingan bersama. Di sisi lain, teknologi dan merek asing yang datang ke Indonesia untuk dipasarkan, adalah bentuk-betuk produk yang di negara asalnya sudah dilindungi oleh HKI. Beberapa di antaranya misalnya minuman merek Coca Cola yang terdaftar sebagai The Coca Cola Company di Amerika Serikat sejak 27 Maret 1944 (Republika, 2013), atau Kentucky Fried Chicken (KFC) merek dagang waralaba dari Yumi Brands Inc yang bermarkas di Amerika Serikat yang didirikan oleh Colonel Harland Sanders (Kontan.co.id, 2020). Di samping itu pula, pada beberapa cabang HKI, beberapa hal yang ada di tengah-tengah masyarakat kita, salah satunya karena kepemilikan komunal atau penemunya tidak lagi diketahui, tidak dapat diberikan perlindungan perspektif HKI, misalnya pengetahuan atau obat-obatan tradisional. Beberapa kasus di antaranya adalah pembajakan keanekaragaman hayati dari pengetahun obat-obatan tradisional Indonesia, yakni dipatenkannya tanaman brotowali oleh perusahaan Jepang (Rosidawati, 2013).

Pengetahuan tradisional yang dimaksud sebagian besar di antaranya berada di tengahtengah masyarakat Indonesia yang sebagian besar ada di daerah. Hal ini selain ruang lingkup perlindungan HKI semakin meluas, objek yang dimaksud pun tidak hanya ada di satu tempat saja. Dalam konteks Indonesia, objek-objek yang berpotensi diberikan perlindungan menyebar di berbagai daerah. Oleh sebab itu, keterlibatan pemerintah daerah, baik 
pemerintah provinsi maupun kabupaten/ kota, dalam hal ini sangat dibutuhkan dalam memaksimalkan perlindungan di bidang HKI. Di samping itu, sesuai dengan ketentuan Pasal 9 Ayat (1) Undang-Undang Nomor 23 Tahun 2014 tentang Pemerintahan Daerah (UU Pemerintah Daerah) disebutkan urusan pemerintahan terdiri atas urusan pemerintahan absolut, urusan pemerintahan konkuren, dan urusan pemerintahan umum. Sementara itu, kewenangan pemerintahan daerah dapat dibedakan menjadi dua, yaitu kewenangan pemerintahan wajib dan pilihan. Adapun kewenangan pemerintah yang bersifat pilihan terkait dengan potensi unggulan dan kekhasan daerah tertentu, dalam konteks ini termasuk kekayaan hayati yang dimiliki dan menjadi ciri khas sebuah daerah.

Hanya saja, dari regulasi yang ada, politik hukum dalam pengaturan hak kekayaan intelektual tidak melibatkan pemerintah daerah di semua cabang HKI. Pemerintah daerah dilibatkan hanya dalam perlindungan indikasi georgafis, yang tertuang dalam UndangUndang Nomor 20 Tahun 2016 tentang Merek dan Indikasi Geografis (UU Merek dan Indikasi Geografis). Penelitian ini bertujuan untuk mengetahui dan menganalisis bagaimana politik hukum kewenangan pemeintah daerah dalam peraturan perundang-undangan bidang HKI di Indonesia. Oleh sebab itu, pertanyaan dalam penelitian ini yang hendak dikaji adalah bagaimana politik hukum kewenangan pemeintah daerah dalam peraturan perundangundangan bidang HKI di Indonesia?

\section{METODE PENELITIAN}

Penelitian ini adalah penelitian hukum normatif atau yang lazim pula disebut sebagai penelitian kepustakaan, yakni penelitian hukum yang dilakukan dengan cara meneliti bahan pustaka atau data sekunder belaka, meliputi penelitian terhadap asas-asas hukum, sistematik hukum, taraf sinkronisasi vertikal dan horizontal, perbandingan hukum dan sejarah hukum (Soekanto \& Mamudji, 2015). Penelitian hukum normatif meneliti hukum dari perspektif internal dengan objek penelitiannya adalah norma hukum (Diantha, 2017). Pendekatan yang digunakan dalam penelitian ini yakni pendekatan perundang-undangan (statute approach), yakni penelitian yang dilakukan dengan menelaah semua undang-undang dan regulasi yang bersangkut paut dengan isu hukum yang sedang ditangani (Marzuki, 2016). Sumber data yang digunakan merupakan sumber data sekunder, yakni data yang diperoleh dari bahan kepustakaan atau literatur yang mempunyai hubungan dengan objek penelian. Teknik pengumpulan data yang digunakan adalah studi literatur, yakni studi yang mengkaji tentang berbagai dokumen-dokumen, baik yang berkaitan dengan peraturan perundang-undangan maupun dokumen-dokumen yangs sudah ada. Teknik nalisis data yang bersifat kualitatif, yakni analisis yang tidak menggunakan angka, melainkan memberikan gambaran-gambaran (deskripsi) dengan kata, atau temuan-temuan, dan karenanya ia lebih mengutamakan mutu/ kualitas dari data, dan bukan kuantitas (Salim \& Nurbani, 2013).

\section{HASIL PENELITIAN}

\section{Kausul Politik Hukum dan Hak Kekayaan Intelektual}

Secara etimologis politik hukum merupakan terjemahan dari istilah hukum Belanda rechtspolitiek, yang merupakan bentukan dari dua kata recht dan politiek. Adapun dalam kamus bahasa Belanda yang ditulis oleh Van der Tas, kata politiek mengandung arti beleid yang dalam bahasa Indonesia berarti kebijakan (policy). Dari penjelasan itu bisa dikatakan bahwa politik hukum secara singkat berarti kebijakan hukum (Syaukani \& Thihari, 2010).

Beberapa ahli mengutarakan definisi dari politik hukum. Menurut Padmo Wahjono politik hukum adalah kebijakan penyelenggara negara yang bersifat mendasar dalam menentukan arah, bentuk maupun isi dari hukum yang akan dibentuk dan tentang apa yang dijadikan kriteria untuk menghukumkan sesuatu, yakni berkaitan dengan hukum yang berlaku 
di masa mendatang (ius constituendum) hukum (Syaukani \& Thihari, 2010). Sementara itu, Teuku Mohammad Radhie mendefinisikan politik hukum sebagai suatu pernyataan kehendak penguasa negara mengenai hukum yang berlaku di wilayahnya dan mengenai arah perkembangan hukum yang dibangun, mencakup ius constituendum atau hukum yang berlaku di wilayah negara pada saat ini dan ius constitunendum atau hukum yang akan atau seharusnya diberlakukan di masa mendatang hukum (Syaukani \& Thihari, 2010; Mahfud, 2011).

Menurut Soedarto, politik hukum adalah kebijakan dari negara melalui badan-badan negara yang berwenang untuk menetapkan peraturan yang dikehendaki, yang diperkirakan akan digunakan untuk mengekspresikan apa yang terkandung dalam masyarakat dan untuk mencapai apa yang dicita-citakan (Syaukani \& Thihari, 2010; Latif \& Ali, 2011). Satjipto Rahardjo mendefinisikan politik hukum sebagau aktivitas memilih dan cara yang hendak dipakai umtuk mencapai suatu tujuan sosial dengan hukum tertentu di dalam masyarakat (Syaukani \& Thihari, 2010; Latif \& Ali, 2011).

Muchtar Kusumatmadja mengatakan politik hukum adalah kebijakan hukum dan perundang-undangan, dalam rangka pembaruan hukum, yang apabila dikaitkan dengan pengertian hukum adalah menyangkut hukum mana yang perlu dibentuk (diperbaharui, diubah arau diganti) dan hukum mana yang harus dipertahankan agar secara bertahap tujuan negara dapat terwujud (Latif \& Ali, 2011). Sementara itu, Solly Lubis mendefinisikan politik hukum sebagai kebijakan politik yang menentukan aturan hukum apa yang seharusnya berlaku mengatur berbagai hal kehidupan masyarakat dan bernegara (Latif \& Ali, 2011). Menurut Abdul Hakim Garuda Nusantara, secara harfiah politik hukum diartikan sebagai kebijakan hukum (legal policy) yang hendak diterapkan secara nasional oleh pemerintah, yang meliputi penerapan hukum positif secara konsisten, pembangunan hukum dan pembaruan hukum postif yang dianggap telah ketinggalan zaman atau menciptakan hukum baru sesuai dengan perkembangan yang terjadi dalam masyarakat, penegasan fungsi dan kewenangan lembaga penegak hukum dan peningkatan kesadaran hukum masyarakat (Irawan, 2011).

Moh. Mahfud MD mengatakan bahwa politik hukum adalah legal policy atau garis (kebijakan) resmi tentang hukum yang akan diberlakukan baik dengan pembutan hukum baru maupun dengan penggantian hukum lama, dalam rangka mencapai tujuan negara. Politik hukum dengan demikian merupakan pilihan tentang hukum yang akan diberlakukan sekaligus pilihan tentang hukum-hukum yang akan dicabut atau tidak diberlakukan yang kesemuanya dimaksudkan untuk mencapai tujuan negara seperti yang tercantum di dalam Pembukaan Undang Dasar Negara Republik Indonesia Tahun 1945 (UUD NRI) 1945 (Mahfud, 2017).

Setelah mempelajari pendapat-pendapat para ahli di atas, politik hukum dapat dirumuskan sebagai upaya yang dilakukan oleh pemerintah untuk mewujudkan tujuan negara yang dicita-citakan dan tertuang dalam suatu kebijakan hukum (legal policy). Berdasarkan pengertian tersebut dapat pula dirumuskan ruang lingkup kajian politik hukum, meliputi; (1) dasar berlakunya hukum positif (aspek filosofis, yuridis, dan sosiologis); (2) kebijakan hukum pemerintah (legal policy) untuk mewujudkan tujuan hukum dala kehidupan berbangsa dan bernegara; (3) studi terhadap hukum positif yang sudah ada untuk kemudian melakukan amandemen atau perubahan jika ditemukan ketidaksesuaian dengan perkembangan masyarakat; (4) menciptakan hukum baru yang sesuai dengan kebutuhan dan perkembangan masyarakat serta pergaulan internasional; dan (5) penegasan mengenai kewenangan lembagalembaga negara yang merumus tujuan hukum nasional, pembuatan hukum dan melaksanakan hukum secara nyata. Politik hukum HKI adalah kebijakan hukum yang dilakukan oleh pemerintah untuk mewujudkan tujuan peraturan perundang-undangan HKI, kajian mengenai kesesuaiannya dengan kebutuhan masyarakat Indonesia (kepentingan nasional) serta kesesuaianya dengan Pancasila dan UUD NRI 1945, dan melakukan amandemen atau 
menciptakan peraturan perundang-undangan baru yang lebih sesuai dengan kepentingan nasional serta serta tidak bertentangan dengan Pancasila dan UUD NRI 1945 (Irawan, 2011).

\section{Hak Kekayaan Intelektual dan Pengaturannya di Indonesia}

Secara sederhana, HKI merupakan hak yang dimiliki oleh seseorang secara individual atau beberapa orang maupun badan hukum secara komunal atas hasil kreativitasnya dalam mengolah akal dan pikiran, yakni mengolah ide dan gagasan, dan mewujudkannya menjadi sesuatu yang betul-betul nyata. Perlindungan yang dimaksud bukan diberikan kepada benda sebagai wujud kreativitas, tetapi ide dan gagasan yang ada di balik terciptanya benda itu. Ide dan gagasan itulah yang tidak dimiliki oleh setiap manusia (Darwance, Yokotani \& Anggita, 2020).

HKI pada dasarnya sulit diberikan definsi tapi dapat dijelaskan dengan contoh-contoh (Lindsey dkk, 2013). Misalnya, HKI melekat pada sebuah karya berbentuk buku, lagu, dan karya sastra seperti cerita pendek atau novel. Menurut Eddy Damian, HKI merupakan kekayaan tidak berwujud (intangible) hasil olah pikir atau kreativitas manusia yang menghasilkan suatu ciptaan atau invensi di bidang seni, sastra, ilmu pengetahuan dan teknologi yang mempunyai manfaat ekonomi (Imaniyati, 2010). Sementara Rachmadi Usman mengartikan HKI sebagai hak atas kepemilikan atas karya-karya yang timbul atau lahir karena adanya kemampuan intelektualitas manusia dalam ilmu pengetahuan dan teknologi (Usman, 2002).

HKI lazimnya dibagi atas dua kelompok, yakni hak milik perindustrian (industrialpropertyrights) dan hak cipta (copyrights). Hak milik perindustrian meliputi paten (patents), merek (trademarks), desain industri (industrialdesign), dan lain-lain. Sedangkan yang termasuk dalam hak cipta dibedakan antara hak cipta (atas seni, sastra, dan ilmu pengetahuan) dan hak-hak yang terkait dengan hak cipta (neigbouringrights). Perbedaan pokok antara hak milik perindustrian dengan hak cipta terletak pada dasar-dasar lahirnya perlindungan. Perlindungan terhadap hak milik perindustrian lahir sejak pengakuan hak tersebut diberikan oleh negara. Dalam hal ini, pendaftaran hak milik industri merupakan suatu keharusan. Sedangkan hak cipta mengenal asas perlindungan otomatis (automaticalprotection) (Hasibuan, 2006).

Pengaturan yang mengaturnya adalah Undang-Undang Nomor 28 Tahun 2014 tentang Hak Cipta, Undang-Undang Nomor 13 Tahun 2016 tentang Paten, Undang-Undang Nomor 30 Tahun 2000 tentang Rahasia Dagang, Undang-Undang Nomor 20 Tahun 2016 tentang Merek dan Indikasi Geografis, Undang-Undang Nomor 31 Tahun 2000 tentang Desain Industri, Undang-Undang Nomor 32 Tahun 2000 tentang Desain Tata Letak Sirkuit Terpadu, dan Undang-Undang Nomor 29 Tahun 2000 tentang Perlindungan Varietas Tanaman.

\section{PEMBAHASAN}

\section{Kewenangan Pemerintah Daerah Dalam Pengaturan HKI}

Penyelenggaraan pemerintahan daerah merupakan bentuk realisasi dari UUD NRI 1945, bertujuan agar pemerintah daerah menjadi bagian dari sistem pemerintahan Indonesia sebagai upaya mengatur hubungan antara pemerintah pusat dan pemerintah daerah. Pada prinsipya, kewenangan pemerintahan daerah dibedakan menjadi dua, yaitu kewenangan pemerintahan wajib dan pilihan. Kewenangan pemerintah yang bersifat pilihan terkait dengan potensi unggulan dan kekhasan daerah tertentu. Pada hakikatnya urusan pemerintah pusat yang diserahkan kepada pemerintah daerah adalah urusan pemerintah daerah dalam menyelenggarakan semua urusan pemerintahan kecuali urusan politik luar negeri, pertahanan, keamanan, yustisi, moneter dan fiskal nasional serta agama (Antikowati \& Indrayati, 2017). Dalam bidang hukum dan hak asasi manusia misalnya, di daerah ada Kantor Wilayah Kementerian Hukum dan Hak Asasi Manusia yang menjadi wakil pemerintah pusat dalam urusan hukum dan hak asasi manusia. 
Selain itu, otonomi daerah dalam sistem negara kesatuan seperti Indonesia ditekankan pada adanya kemandirian daerah untuk mengurus dan mejalankan sebagian urusan yang menjadi wewenangnya. Otonomi daerah dengan demikian bukan berarti kemerdekaan dalam setiap pengambilan kebijakan, tetapi kewenangan yang harus berdasarkan peraturan perundang-undangan yang berlaku (Hakim, 2012). Di sisi lain, pemberian urusan dengan kewenangan yang luas, nyata dan bertanggung jawab kepada daerah mengandung dua pengertian, yaitu pemberian urusan diberikan sepenuhnya, namun tidak semua urusan diberikan kepada pemerintah daerah melainkan sebagian urusan Negara Kesatuan Republik Indonesia. Pembagian urusan otonomi daerah tersebut secara proporsional, yang mengandung pengertian, bahwa pembagian urusan yang dimaksud memperhatikan proporsi atau bagian yang berimbang masing-masing pihak, dalam hal ini pihak pemerintah pusat dan pihak pemerintah daerah (Huda, 2012).

Sebagai bentuk perpanjangan tangan dari pusat dan sebagai unsur penyelenggara pemerintahan daerah, pemerintah daerah mempunyai peranan untuk memimpin pelaksanaan urusan pemerintahan yang menjadi kewenangan daerah otonom. UU Pemerintah Daerah secara jelas memberikan kewenangan penuh bagi daerah untuk mengelola potensi daerah apa saja yang mengandung nilai ekonomis (Purwaka, 2017). Dalam konteks otonomi daerah, pemerintah daerah memiliki kewenangan dalam mengurus pemerintahannya sendiri dengan memperhatikan prinsip demokrasi, pemerataan, keadilan yang pada dasarnya diarahkan untuk mempercepat terwujudnya kesejahteraan masyarakat melalui peningkatan, pelayanan, pemberdayaan, dan peran serta masyarakat yang ada di daerah. Selain itu, dengan kewenangan yang dimiliki tersebut akan meningkatan daya saing daerah.

Berkaitan dengan HKI, ternyata tidak semua undang-undang tentang HKI yang memberikan kewenangan kepada pemerintah daerah. Dalam Undang-Undang Nomor 28 Tahun 2014 tentang Hak Cipta (UUHC) politik hukum mengendaki tidak ada peran pemerintah daerah dalam perlindungan hak cipta. Hal yang sama juga terjadi pada UndangUndang Nomor 13 Tahun 2016 tentang Paten (UU Paten). Pembentuk undang-undang juga menyepakati tidak adanya peran pemerintah daerah dalam perlindungan paten. Sementara itu, dalam Undang-Undang Nomor 20 Tahun 2016 tentang Merek dan Indikasi Geografis (UU Merek dan Indikasi Geografis), politik hukum menghendaki adanya keterlibatan pemerintah daerah. Hal ini dapat dijumpai pada beberapa ketentuan, yakni pasal-pasal yang khusus mengatur tentang indikasi geografis. Sesuai dengan ketentuan Pasal 1 Angka 6 UU Merek dan Indikasi Geografis, indikasi geografis pada prinsipnya merupakan tanda yang mengindikasikan daerah asal suatu barang, daerah asal suatu produk dikarenakan faktor lingkungan geografis. Faktor lingkungan geografis yang dimaksud termasuk termasuk di dalamnya adalah faktor alam, manusia atau kombinasi keduanya. Dari faktor-faktor inilah kemudian lahir reputasi, kualitas, dan karakteristik tertentu pada barang dan/atau produk yang dihasilkan itu.

Lalu, seuai dengan ketentuan Pasal 53 UU Merek dan Indikasi Geografis dikatakan indikasi geografis dilindungi setelah didaftar oleh menteri, dalam konteks ini yakni menteri hukum dan Hak Asasi Manusia (HAM). Ini berarti bahwa indikasi geografis perlindungannya tidak bersifat otomatis, perlu didaftarkan terlebih dahulu sebelum mendapatkan proteksi secara normatif, yakni setelah pemohon mengajukan permohonan kepada menteri. Permohonan dapat diajukan oleh lembaga yang mewakili masyarakat di kawasan geografis tertentu yang mengusahakan suatu barang dan/atau produk berupa sumber daya alam, barang kerajinan tangan atau hasil industri. Selain itu, permohonan bisa juga dilakukan oleh pemerintah daerah, yakni pemerintah provinsi atau pemerintah kabupaten kabupaten/ kota. Pemerintah daerah dengan demikian bisa berposisi sebagai pemohon.

Selain berperan sebagai pemohon, dalam perlindungan indikasi geografis pemerintah daerah juga memiliki peran dalam hal pembinanan dan pengawasan. Hal ini sesuai dengan ketentuan Pasal 70 Ayat (1) UU Merek dan Indikasi Geografis yang secara eksplisit 
menyebutkan bahwa pembinaan indikasi geografis dilakukan oleh pemerintah pusat dan/atau pemerintah daerah sesuai dengan kewenangannya. Pembinaan yang dimaksud, sebagaimana ketentuan Pasal 70 Ayat (2), meliputi persiapan untuk pemenuhan persyaratan permohonan indikasi geografis; permohonan pendaftaran indikasi geografis; pemanfaatan dan komersialisasi indikasi geografis; sosialisasi dan pemahaman atas perindungan indikasi geografis; pemetaan dan inventarisasi potensi produk indikasi geografis; pelatihan dan pendampingan; pemantauan, evaluasi, dan pembinaan; pelindungan hukum; dan fasilitasi pengembangan, pengolahan, dan pemasaran barang dan/atau produk indikasi geografis.

Sedangkan soal pengawasan diatur dalam Pasal 71. pengawasan indikasi geografis dilakukan oleh pemerintah pusat dan pemerintah daerah sesuai dengan kewenangannya. Tidak ada penjelasan lebih lanjut kewenangan seperti apa yang dimaksud pada ketentuan ini, termasuk pada bagian penjelasan. Oleh sebab itu, ada beberapa alternatif untuk memaknai isi ketentuan ini, salah satunya merujuk kepada peraturan perundang-undangan yang khusus mengatur tentang kewenangan pemerintah daerah, atau pembagian urusan antara pemerintah pusat dan pemerintah daerah. Selain itu, pengawasan menurut undang-undang ini juga dapat pula dilakukan oleh masyarakat. Baik pengawasan yang dilakukan oleh pemerintah pusat dan pemerintah daerah maupun oleh masyarakat, semuanya dilakukan untuk menjamin tetap adanya reputasi, kualitas, dan karakteristik yang menjadi dasar diterbitkannya indikasi geografis, serta mencegah penggunaan indikasi geografis secara tidak sah. Hasil pengawasan selanjutnya disampaikan kepada pemegang hak indikasi geografis dan/atau menteri.

Selain di UU Merek dan Indikasi Geografis, peran pemerintah daerah tidak dijumpai dalam UU HKI yang lain. Undang-Undang Nomor 29 Tahun 2000 tentang Perlindungan Varietas Tanaman (PVT), tidak ada peran pemerintah daerah. Undang-Undang Nomor 30 Tahun 2000 tentang Rahasia Dagang tidak ada peran pemerintah daerah. Undang-Undang Nomor 31 Tahun 2000 tentang Desain Industri, tidak ada peran pemerintah daerah. UndangUndang Nomor 32 Tahun 2000 tentang Desain Tata Letak Sirkuit Terpadu, tidak ada peran pemerintah daerah.

Seperti yang sudah disampaikan sebelumnya, politik hukum pada dasarnya merupakan kebijakan hukum atau kebijakan penyelenggara negara dalam menentukan arah, bentuk maupun isi dari hukum yang yang dikehendaki, menyangkut hukum mana yang perlu dibentuk (diperbaharui, diubah arau diganti) dan hukum mana yang harus dipertahankan dalam rangka mencapai tujuan negara. Dalam konteks Indonesia, tujuan negara tercantum pada alinea keempat UUD NRI 1945, meliputi melindungi segenap bangsa dan seluruh tumpah darah Indonesia, memajukan kesejahteraan umum, mencerdaskan kehidupan bangsa, serta ikut melaksanakan ketertiban dunia berdasarkan kemerdekaan, perdamaian abadi dan keadilan sosial. Tujuan memajukan kesejahteraan umum adalah tujuan negara kesejahteraan, yakni mencapai kesejahteraan bagi seluruh rakyat Indonesia, tidak hanya dari segi material/ ekonomi saja tetapi juga dari segi spiritual (Soemarsono, 2007).

Dalam teori ilmu negara, masalah tujuan negara dapat dilihat dari 3 (tiga) sudut pandang, yakni tujuan negara berkaitan dengan tujuan akhir manusia, tujuan kekuasaan, dan tujuan kemakmuran. Dalam kaitannya dengan kewenangan pemerintah daerah dalam peraturan perundang-undangan atau pengaturan yang berkaitan dengan HKI, teori negara hukum dengan tujuan kemakmuran relevan untuk dijadikan sebagai bahan kajian. Teori tujuan kemakmuran, terbagi menjadi teori tujuan kemakmuran negara, kemakmuran individu dan teori tujuan kemakmuran rakyat (Soemarsono, 2007). Hal ini sejalan dengan salah satu hak yang ada dalam sebuah karya intelektual seorang atau beberapa orang manusia selain hak moral, yakni hak ekonomi. Hak ekonomi yang terkandung dalam sebuah karya intelektual seharusnya dapat memberikan kemakmuran kepada pemilik karya itu, termasuk yang sifatnya dimiliki bersama-sama (komunal). Hanya saja, sistem individualistik yang dominan pada sistem kepemilikan HKI menuntut peran dan kewenangan badan hukum publik seperti pemerintah daerah dalam upaya perlindungan agar potensi yang ada tidak diklaim terutama 
oleh pihak asing. Selain sebagai pihak yang bisa ikut menjadi pemohon, pemerintah daerah juga seharusnya diberikan kewenangan untuk mendorong upaya perlindungan di level daerah.

Kekuasan pemerintahan adalah bagian dari sistem kekuasaan negara. Hans Kelsen mengnggap negara sebagai badan hukum (rechtpersoon) memiliki hak dan kewajiban, di samping memiliki kekuataan untuk membentuk hukum (mengatur) (Hakim, 2011). Pemerintahan yang dimaksud di sini dapat ditafsirkan meliputi pemerintah daerah sebagai bagian dari sistem pemerintahan sebuah negara. Di samping itu, sebagaimana yang sudah disampaikan sebelumnya, pemerintah daerah memiliki kewenangan yang bersifat pilihan terkait dengan potensi unggulan dan kekhasan daerah tertentu. Pada prinsipnya, urusan yang diberikan kepada pemerintah daerah oleh pemerintah pusat adalah semua urusan pemerintahan, kecual yang berkaitan dengan politik luar negeri, pertahanan, keamanan, yustisi, moneter, fiskal dan agama (Farid, Antikowati, \& Indrayati, 2017).

Dalam konteks perlindungan HKI, potensi yang dimiliki oleh deaerah sekaligus kekayaan yang berpotensi diberikan perlindungan perspektif HKI pun menjadi urusan pemerintah daerah. Hanya saja, politik hukum pembentuk peraturan perundang-undangan HKI di Indonesia belum memberikan ruang kepada pemerintah daerah untuk lebih leluasa mengurusi persoalan perlindungan HKI. Buktinya, dari 7 peraturan perundang-undangan yang mengatur tentang HKI, hanya satu undang-undang yang menyebutkan secara eksplisit kewenangan kepada pemerintah daerah, yakni UU Merek dan Indikasi Geografis. Selebihnya tidak ada sama sekali. Sekalipun diatur, penyebutannya bersifat umum, misalnya penggunaan istilah "negara" dalam UU Hak Cipta sebagai pemegang ekspresi budaya tradisional dan hak cipta atas ciptaan yang penciptanya tidak diketahui.

Dalam konteks negara hukum, wewenang pemerintahan berasal dari peraturan perundang-undangan yang berlaku. Dengan kata lain, dalam hal ini kewenangan hanya diberikan oleh undang-undang. Menurut Ridwan HR, pembuat undang-undang dapat memberikan wewenang pemerintahan tidak hanya kepada organ pemerintahan, tetapi juga terhadap pegawai atau terhadap badan khusus atau bahkan terhadap badan hukum privat (HSB \& Julianthy, 2018). Hal ini sejalan dengan asas legalitas yang merupakan dasar dalam setiap penyelenggaraa kenegaraan dan pemerintahan, yakni setiap penyelenggaraan kenegaraan dan pemerintahan harus memiliki legitimasi berupa kewenangan yang diberikan oleh undang-undang (Said, 2015).

\section{SIMPULAN}

Sampai saat ini, Indonesia sudah memiliki tatatan regulasi yang mengatur tentang HKI. Selain sebagai impilikasi dari keikutseraan Indonesia di beberapa organisasi dan ratifikasi terhadap ketentuan HKI secara global, regulasi yang tertuang dalam berbagai undang-undang ini dimaksudkan agar kekayaan intelektual yang dimiliki oleh manusia Indonesia dapat dilindungi. Sejumlah regulasi yang ada ini menegaskan peran pemerintah dalam melindungi hak warga negara, sekaligus menjadi sejumlah aset potensial yang dimiliki oleh bangsa ini agar tidak diklaim oleh asing. Pemerintah yang dimaksud adalah pemerintah pusat maupun pemerintah daerah. Pemerintah pusat dalam konteks ini tentu tidak bisa melindungi kekayaan intelektual secara mandiri, butuh dukungan dari berbagai pihak terasuk pemerintah daerah. Hanya saja, dari regulasi yang ada, politik hukum dalam pengaturan HKI tidak melibatkan pemerintah daerah di semua cabang HKI. Pemerintah daerah dilibatkan hanya dalam perlindungan indikasi georgafis, yang tertuang dalam UU Merek dan Indikasi Geografis. Peran yang dimaksud adalah peran pemerintah daerah dalam hal pembinaan dan pengawasan. Selebihnya tidak ada sama sekali. Sekalipun diatur, penyebutannya bersifat umum, misalnya penggunaan istilah "negara" dalam UU Hak Cipta sebagai pemegang ekspresi budaya tradisional dan hak cipta atas ciptaan yang penciptanya tidak diketahui. 


\section{UCAPAN TERIMA KASIH}

Terimakasih disampaikan kepada Kementerian Riset dan Teknologi/ Badan Riset dan Inovasi Nasional Republik Indonesia yang sudah mendanai penelitian ini melalui skim Penelitian Dosen Pemula (PDP) tahun pendanaan 2020 yang tertuang dalam kontak Nomor 035/SP2H/LT/DPRM/2020.

\section{DAFTAR PUSTAKA}

Darwance, Yokotani, \& Anggita, W. (2020). Dasar-Dasar Pemikiran Perlindungan Hak Kekayaan Intelektual. Progresif: Jurnal Hukum Volume 14 Nomor 2, 193-208. https://doi.org/10.33019/progresif.v15i2.1998

Diantha, I. M. (2017). Metodologi Penelitian Hukum Normatif Dalam Justifikasi Teori Hukum. Jakarta: Kencana.

Farid, M., Antikowati, \& Indrayati, R. (2017). Kewenangan Pemerintah Daerah dan Partisipasi Masyarakat dalam Pengelolaan Potensi Daerah. e-Journal Lentera Hukum, 71-84.

Hakim, L. (2011). Kewenangan Organ Negara Dalam Penyelenggaraan Pemerintahan. Jurnal Konstitusi Volume IV Nomor 1 Juni, 103-130. http://publishingwidyagama.ac.id/ejournal-v2/index.php/jk/article/view/302

Hakim, L. (2012). Filosofi Kewenangan Organ dan Kelembagaan Daerah. Malang: Setara Press.

Hasibuan, O. (2006). Perlindungan Hak Ekonomi Pencipta Lagu dan Pemegang Hak Terkait di Indonesia (Ringkasan Desertasi). Yogyakarta: Universitas Gajah Mada.

Huda, N. (2012). Hukum Pemerintah Daerah. Bandung: Nusa Media.

HSB, A. M., \& Julianthy, E. M. (2018). Pelaksanaan Kewenangan Atribusi Pemerintahan Daerah Berdasarkan Undang-Undang Nomor 23 Tahun 2014 tentang Pemerintah Daerah. Jurnal Legislasi Indonesia Volume 15 Nomor 2 Juli, 1-8. https://ejurnal.peraturan.go.id/index.php/jli/article/view/164

Imaniyati, N. S. (2010). Perlindungan HKI Sebagai Upaya Pemenuhan Hak Atas Iptek, Budaya dan Seni. Jurnal Media Hukum Volume 17 Nomor 1 Juni, 162-176. https://journal.umy.ac.id/index.php/jmh/article/view/374

Irawan, C. (2011). Politik Hukum Hak Kekayaan Intelektual Indonesia. Bandung: Mandar Maju. 
Kontan.co.id. (2020, Oktober 8). Suka makan kulit ayam KFC? Ini sejarah KFC di Indonesia. Retrieved from kontan.co.id: https://amp.kontan.co.id/news/suka-makankulit-ayam-kfc-ini-sejarah-kfc-di-indonesia

Latif, A., \& Ali, H. (2011). Politik Hukum. Jakarta: Sinar Grafika.

Lindsey, T., Damian, E., Butt, S., \& Utomo, T. S. (2013). Hak Kekayaan Intelektual Suatu Pengantar. Bandung: Alumni.

Marzuki, P. M. (2016). Penelitian Hukum (Edisi Revisi). Jakarta: Kencana.

Mahfud, M. (2011). Membangun Politik Hukum, Menegakan Konstitusi. Jakarta: Rajawali Press.

Mahfud, M. (2017). Politik Hukum di Indonesia. Jakarta: Rajawali Press.

Purwaka, T. H. (2017). Pelindungan Merek. Jakarta: Yayasan Pustaka Obor Indonesia.

Republika. (2013, Mei 8). Hari Ini di 1886, John Pemberton Memperkenalkan Coca Cola. Retrieved from republika.co.id: https://republika.co.id/berita/mmb3r9/hari-ini-di-1886john-pemberton-memperkenalkan-coca-cola

Rosidawati, W. I. (2013). Konsep Perlindungan Pengetahuan Tradisional Berdasarkan Asas Keadilan Melalui Sui Generis (Undang-Undang Republik Indonesia Nomor 13, 2016) Intellectual Propertu System. Jurnal Hukum Ius Quia Iustum Volume 20 Nomor 2, 163185. https://doi.org/10.20885/iustum.vol20.iss2.art1

Rout, S. K. (2018). A Brief Revoew on Intellectual Property Rights with Special Attention on Patent, Journal of Apllied and Advanced Research. Journal Applied and Advanced Research Volume 3 Nomor 2, 73-77.

Said, A. R. (2015). Pembagian Kewenangan Pemerintah Pusat-Pemerintah Daerah Dalam Otonomi Seluas-Luasnya Menurut UUD 1945. Fiat Justicia Jurnal Ilmu Hukum Volume 9 Nomor 4 Oktober - Desember, 577-602.

Saidin, O. (2019). Aspek Hukum Hak Kekayaan Intelektual (Intellectual Property Righs), RajaGrafindo Persada. Jakarta: Raja Grafindo Persada.

Salim, H.S. \& Nurbani, E. S. (2013). Penerapan Teori Hukum Pada Penelitian Tesis dan Disertasi. Jakarta: Raja Grafindo Persada.

Soekanto, S., \& Mamudji, S. (2015). Penelitian Hukum Normatif Suatu Tinjauan Singkat. Jakarta: Jaja Grafindo Persada. 
Soemarsono, M. (2007). Negara Hukum Indonesia Ditinjau Dari Sudut Teori Tujuan Negara. Jurnal Hukum dan Pembangunan Tahun ke-37 Nomor 2 April - Juni, 300-322.

Syaukani, I., \& Thihari, A. A. (2010). Dasar-dasar Politik Hukum. Jakarta: Rajawali Press.

Undang-Undang Republik Indonesia Nomor 29 Tahun 2000 tentang Varietas Tanaman.

Undang-Undang Republik Indonesia Nomor 30 Tahun 2000 tentang Rahasia Dagang.

Undang-Undang Republik Indonesia Nomor 31 Tahun 2000 tentang Desain Industri.

Undang-Undang Republik Indonesia Nomor 32 Tahun 2000 tentang Desain Tata Letak Sirkuit Terpadu.

Undang-Undang Republik Indonesia Nomor 13 Tahun 2016 tentang Paten.

Undang-Undang Republik Indonesia Nomor 20 Tahun 2016 tentang Merek.

Undang-Undang Republik Indonesia Nomor 23 Tahun 2014 tentang Pemerintahan Daerah.

Undang-Undang Republik Indonesia Nomor 28 Tahun 2016 tentang Hak Cipta.

Usman, R. (2002). Hukum Hak atas Kekayaan Intelektual; Perlindungan dan Dimensi Hukumnya di Indonesia. Bandung: Alumni. 